IX International Scientific Symposium

"Farm Machinery and Processes Management in Sustainable Agriculture", Lublin, Poland, 2017

DOI: $10.24326 /$ fmpmsa.2017.34

\title{
STABILIZATION OF LIQUID OUTFLOW SPEED FROM A SLOTTED SPRAY NOZZLE
}

\author{
Witold KOWALIK, Stanisław PARAFINIUK \\ Department of Machinery Exploitation and Management of Production Processes, University of Life \\ Sciences in Lublin, POLAND \\ E-mail: witold.kowalik@up.lublin.pl
}

Keywords: slotted spray nozzle, technical parameters, outflow speed

\begin{abstract}
Unequal distribution of the liquid outflow from the slotted spray nozzle forms a wide spectrum of drops. This affects the level and uniformity of spraying and the degree of drip drift compensation. The purpose of the work was to determine a method of stabilizing the speed of liquid outflow from the nozzle. The result of the study was construction of a speed stabilizer - an insert mounted in the nozzle. Advantage of the patented design is, besides stabilizing the liquid outflow speed, also a uniform flux of liquid flow over the entire length of the nozzle.
\end{abstract}

\section{INTRODUCTION}

One way to protect plants is by spraying them with aqueous solutions of the appropriate substances. Achieving the biological effect of chemical plant protection depends largely on the quality of the spray nozzle work. They affect the level and uniformity of application of the solution and the degree of wind drift compensation, Dorr et al. (2013), Vallet et al. (2013), Szewczyk (2010). Commonly used sprayers in agriculture are slotted spray nozzles. The principal drawback of these nozzles is uneven distribution of liquid flow rate from the nozzle, Vallet et al.(2013), Kowalik (2014). This parameter has a decisive influence on the quality of spraying, since on it depends the resulting droplet spectrum, Dorr et al.(2013), Szewczyk et al.(2013), Truck et al. (1997). In case of slotted spray nozzles this spectrum is unfavorable since diameter of droplets ranges from a few to several hundred micrometers, Hawitt (2008), Orzechowski et al. (2008), Truck et al. (1997). In addition, outflow density in the central nozzle section in these sprayers is much higher than in the outside, which affects the selection and setting of the sprayer boom and the uniformity of spraying, Parafiniuk, Sawa, Wołos (2011), Parafiniuk, Sawa, Huyghebaert (2011). Satisfactory effect is achieved on a flat surface and a sprayer boom parallel to this surface, Szewczyk (2010). Droplet size is now controlled by the use of sprayers with nozzles of different geometrical dimensions, changing pressure of the liquid used, the use of anti-drip inserts, Orzechowski et al. (2008). The range of droplet size control by these methods does not reduce the drop spectrum, but limits the operating parameters of the sprayer. Another way to adjust the droplet size is to aerate them (injectors). With these sprayers, larger diameter droplets are more easily disseminated on the surface of leaves. However, large numbers of large droplets result in less stream density resulting in less droplets per unit area, which influences the biological efficiency of the process, Butler et al.(2002), Szewczyk et al. (2013).

The aim of the study was to determine the conditions that should be met in order to obtain a constant liquid outflow speed from slotted spray nozzle and consequently reduce the drop spectrum. 


\section{MATERIAL AND METHODS OF RESEARCH}

The subject of the study was a slot spray nozzle used in agricultural sprayers. In this nozzle is a channel with $r$ radius ended with spherical surface and an opening that looks like a slot. In the spherical part of the nozzle the surface perpendicular to the liquid flow direction is in the shape of a circle and varies from $\Pi r^{2}$ to 0 . Thus, according to the mass conservation law, the flow velocity of liquid changes inversely proportionally to that surface, (Orzechowski et al. (1997). In the spherical part, a one-dimensional flow model is used for calculating in which only the velocity component parallel to the sprayer axis is considered (perpendicular to the liquid flow surface). The liquid flow surface (nozzle) perpendicular to the stream direction takes the shape of an ellipse with axes $2 \mathrm{a}$ and $2 \mathrm{~b}$. The sprayer was places in a coordinate system in such a way that axis $2 \mathrm{a}$ is located on the $\mathrm{x}$ axis, axis $2 \mathrm{~b}$ on the $\mathrm{y}$ axis and the sprayer axis on the $\mathrm{z}$ axis.

Direct measurement results, slotted spray nozzle output and part of the calculation method were used from a paper to determine the variation of the fluid outflow parameters from the slotted spray nozzle, Kowalik (2014).

In order to calculate the volume of fluid outflowing at a constant velocity $\mathrm{v}$ at the individual points of the nozzle, the ellipse was divided along the long axis $2 \mathrm{a}$ into $\mathrm{n}$ parts $(n \rightarrow \infty)$ with an area of $F_{n}$.

The liquid stream flowing through the area $F_{n}$ at velocity $v$ is:

$$
\Delta \mathrm{Q}_{\mathrm{Rn}}=\mathrm{F}_{\mathrm{n}} \mathrm{V}
$$

The value of the liquid stream flowing through the surface perpendicular to the direction of flow at point $\mathrm{n}$ is:

$$
\mathrm{Q}_{\mathrm{Rn}}=\mathrm{Q}_{\mathrm{Rn}-1}-2 \Delta \mathrm{Q}_{\mathrm{Rn}}
$$

where: $\mathrm{Q}_{\mathrm{Rn}-1}$ - value of the stream flowing through the surface at $\mathrm{n}-1$;

The initial value of the stream at $\mathrm{n}=1$ is:

$$
\mathrm{Q}_{\mathrm{R} 1}=2 \sum_{i=1}^{n} \Delta \mathrm{Q}_{\mathrm{Rn}}
$$

The surface needed for the flow of liquid at the $\mathrm{n}$ point in the volume $\mathrm{Q}_{\mathrm{Rn}}$ at the velocity $\mathrm{v}$ is:

$$
\mathrm{A}_{R n}^{*}=\mathrm{Q}_{\mathrm{Rn} \mathrm{V}}{ }^{-1}
$$

The surface perpendicular to the direction of flow at the point $\mathrm{n}$ of the spherical part of traditional nozzle, Kowalik (2014) pattern 10 and fig. 2 is:

$$
\mathrm{A}_{n}^{*}=\mathrm{A}_{\mathrm{n}}-2 \Delta \mathrm{A}_{\mathrm{n}}
$$

The surface $\mathrm{A}_{n}^{*}$ is larger than surface $\mathrm{A}_{R n}^{*}$ and therefore should be reduced by:

$$
\Delta \mathrm{A}_{n}^{*}=\mathrm{A}_{n}^{*}-\mathrm{A}_{R n}^{*}
$$


The surface $\Delta \mathrm{A}_{n}^{*}$ has the shape of a circle of diameter:

$$
\mathrm{D}_{\mathrm{Rn}}=\sqrt{4 \Delta A_{n}^{*} / \Pi}=2 \mathrm{R}_{\mathrm{n}}
$$

$\mathrm{D}_{\mathrm{Rn}}$ is the diameter of the speed stabilizer insert at point $\mathrm{z}_{\mathrm{n}}$.

The influence of different outflow rates on the $R_{n}$ value for the same nozzle was also analyzed.

\section{RESEARCH RESULTS AND THEIR ANALYSIS}

As a result of the calculations, the design parameters of the slotted spray nozzle were determined to ensure a constant outflow rate of the liquid.
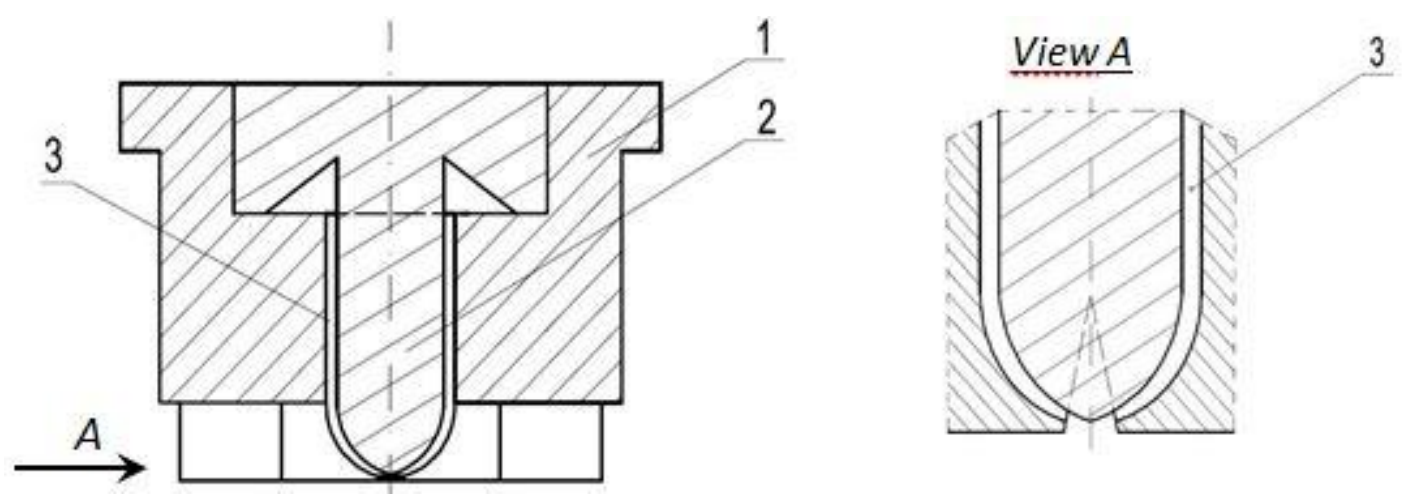

Fig. 1. Speed stabilizer; 1- slotted spray nozzle, 2- speed stabilizer insert, 3-coaxial liquid flow channel

The main component of the speed stabilizer is the insert 2 (fig. 1), which forms a coaxial liquid channel 3 in the spherical part of the nozzle. Dimensions of the stabilizer insert depend on the design parameters of the slot spray nozzle (channel and spherical part diameters and nozzle dimensions) and the flow rate of the work fluid is controlled by pressure change.

Figure 2 shows the mutual dependence of the speed stabilizer height $z_{n}$ and the corresponding radius $R_{n}$. The rotation of the resulting curve around the axis $z_{n}$ shows the shape of the insert in the spherical part of the nozzle. The trend line equation is the pattern of generation function of the speed stabilizer. 


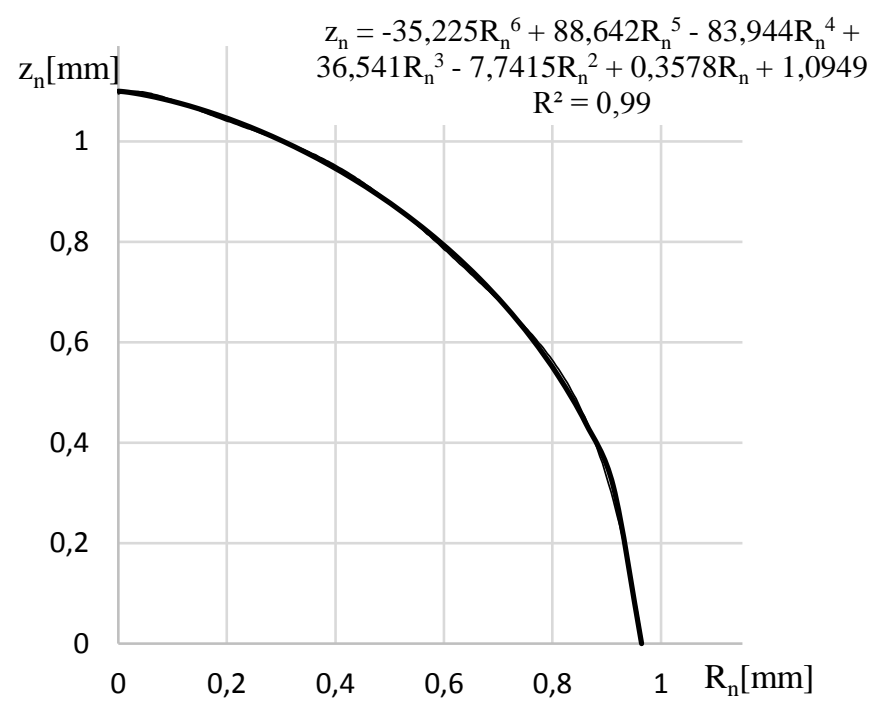

Fig. 2. Generation function of the speed stabilizer

Liquid flow from the slotted spray nozzle at constant speed over the entire length of the nozzle makes the volume flux density $\Delta \mathrm{Q}_{\mathrm{Rn}}$ also constant. As shown in fig. 3, the liquid volume stream for the nozzle without speed stabilizer (curve b) varies from $9 \cdot 10^{-7} \mathrm{~m}^{3} \cdot \mathrm{s}^{-1}$ in the center of the nozzle to zero at extreme outer points. On the other hand, for the same sprayer with a speed stabilizer the calculation showed a stable course of these values almost over the entire length of the nozzle (curve a).

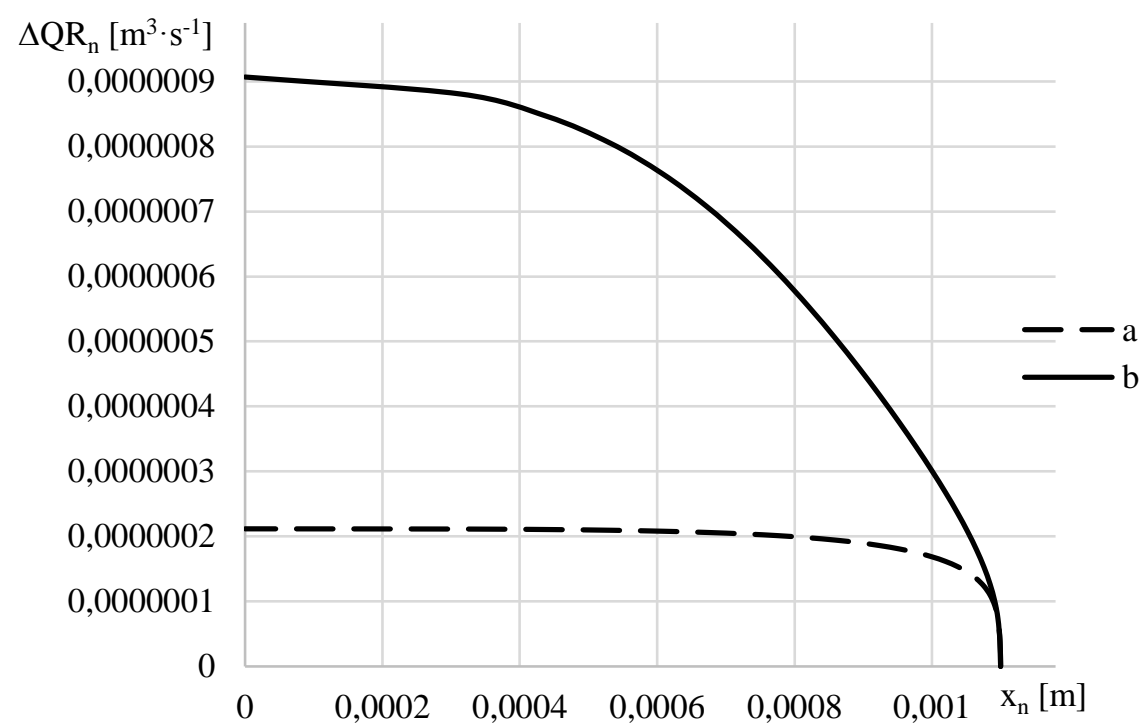

Fig. 3. Liquid volume stream distribution: $\mathrm{a}$ - with a speed stabilizer, $\mathrm{b}$ - in a traditional sprayer

\section{CONCLUSIONS}

1. The outflow of liquid from the slotted spray nozzle with constant speed can be obtained by forming in the spherical part of the sprayer a coaxial channel with a speed stabilizer insert. 
2. The design dimensions of the stabilizer insert depend on the design parameters of the slot spray nozzle.

3. A set of points expressed in the form of functions representing the dependence of the height of the insert in the spherical part and corresponding to that height radius constitutes a generation function of the speed stabilizer.

4. The speed stabilizer insert makes the density of the liquid volume flux at each point of the nozzle equal.

Result of the research was the construction of the speed stabilizer in the slotted spray nozzle (patent P.412369)

\section{BIBLIOGRAPHY}

Butler Ellis M. C., Swan T., Miller P. C. H., Waddelow S., Bradley A., Tuck C.R. (2002). Design factors affecting spray characteristics and drift performance air induction nozzle. Biosystems Engineering. Vol 82(3), 289-296.

Door G.J., Hawitt A.,J., Adkins S.,W., Hanan J., Zhang H., Noller B. (2013). A comparison of initial spray characteristics produced by agricultural nozzle. Crop Protection. Vol. 53, 109-114.

Hawitt A. J. (2008). Droplet size spectra classification categories in aerial application scenarios. Crop Protection. Vol. 27, 1284-1288.

Kowalik W. (2014). Rozkład prędkości wypływu cieczy i gęstości strumienia objętości w dyszy rozpylacza szczelinowego Problemy Inżynierii Rolniczej. Z. 2(84), 41-50.

Orzechowski Z., Prywer J., Zarzycki R. (1997). Mechanika płynów w inżynierii rolniczej. Warszawa, WNT.

Orzechowski Z., Prywer J. (2008). Wytwarzanie i zastosowanie rozpylonej cieczy. Warszawa, WNT.

Parafiniuk S., Sawa J., Wołos D. (2011). Automatyczne urządzenie do oceny stanu technicznego rozpylaczy rolniczych. Postęy Nauki i Techniki. Nr. 10, 39-48.

Parafiniuk S., Sawa J., Huyghebaert B. (2011). Ocena stanu technicznego belki polowej opryskiwacza metodą badania pojedynczych rozpylaczy. Inżynieria Rolnicza. Nr. 12, 207-214.

Szewczyk A. (2010). Analiza ustawienia parametrów i warunków pracy rozpylacza w aspekcie jakości opryskiwania upraw polowych. Monografie XCVII. Wydawnictwo UP we Wrocławiu. ISBN 978-83-7717003-3 ss. 133.

Szewczyk A., Łuczycka D., Owsiak Z., Cieniawska B. (2013). Wpływ wielkości kropel na pokrycie opryskiwanych . Postępy w Ochronie Roślin. 53(4), 822-828.

Truck C.R., Butler Ellis M.C., Miller P.C.H. (1997). Techniques for measurement of droplet size and velocity distributions in agricultural sprays. Crop Protection. Vol 16, 619-628.

Vallet A., Tinet C. (2013). Characteristics of droplets from single and twin jet air induction nozzles: A preliminary investigation. Crop Protection. Vol. 48, 63-68. 